\title{
Developing sustainability learning in business school curricula - productive boundary objects and participatory processes
}

Melissa Edwards, Paul Brown, Suzanne Benn, Christopher Bajada, Robert Perey, Deborah Cotton, Walter Jarvis, Gordon Menzies, Ian McGregor \& Katrina Waite

To cite this article: Melissa Edwards, Paul Brown, Suzanne Benn, Christopher Bajada, Robert Perey, Deborah Cotton, Walter Jarvis, Gordon Menzies, Ian McGregor \& Katrina Waite (2019): Developing sustainability learning in business school curricula - productive boundary objects and participatory processes, Environmental Education Research, DOI: $10.1080 / 13504622.2019 .1696948$

To link to this article: https://doi.org/10.1080/13504622.2019.1696948

Published online: 09 Dec 2019.

Submit your article to this journal $₫$

山ll Article views: 9

Q View related articles ¿

View Crossmark data $־$ 


\title{
Developing sustainability learning in business school curricula - productive boundary objects and participatory processes
}

\author{
Melissa Edwards ${ }^{\mathrm{a}}$ (D), Paul Brown ${ }^{\mathrm{b}}$, Suzanne Benn ${ }^{\mathrm{a}}$, Christopher Bajada $^{\mathrm{c}}$ (D), \\ Robert Perey $^{\mathrm{a}}$ (D), Deborah Cotton ${ }^{\mathrm{d}}$ (D), Walter Jarvis ${ }^{\mathrm{a}}$, Gordon Menzies ${ }^{c}$ (D), \\ Ian McGregor ${ }^{\mathrm{a}}$ and Katrina Waite $\mathrm{e}^{\mathrm{iD}}$
}

\begin{abstract}
${ }^{\mathrm{a}}$ Management, University of Technology, Sydney, Australia; ${ }^{\mathrm{b}}$ Accounting, University of Technology, Sydney, Australia; 'Economics, University of Technology, Sydney, Australia; ${ }^{\mathrm{d}}$ Finance, University of Technology,

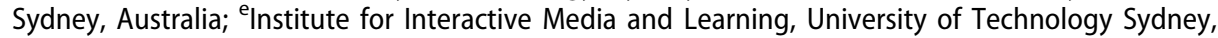
Sydney, Australia
\end{abstract}

\begin{abstract}
Sustainability learning is holistic and complex as it draws on diverse disciplines and can be interpreted differently within individual pedagogies. Embedding sustainability across and within business schools relies on developing suitable boundary objects. These may include representations such as models, frameworks or classificatory schemes that are malleable enough to be adapted for use within the disparate disciplines and pedagogies, yet durable enough to be recognisable and to maintain consistency across them. Boundary objects thus allow the sharing of ways of knowing or practice across various social boundaries. This paper outlines how participatory curriculum development processes can enable sustainability to be embedded in a business school curriculum. Distinct phases of the process were marked by different ways of knowing, as disciplinary-specific academics developed and embedded sustainability into and across curricula. Boundary objects were both outcomes and productive facilitators of this process. They acted as catalysts and attracted ongoing processes of dialogue, debate and meaning-making between these academics. The institutional context provided enabling conditions to legitimize outcomes from the participatory process. The process may be replicable in other business schools by the use of boundary objects.
\end{abstract}

\section{ARTICLE HISTORY}

Received 2 April 2019

Accepted 15 November 2019

\section{KEYWORDS}

Sustainability; curriculum; participatory process; multidisciplinary; transdisciplinary; boundary objects

\section{Introduction}

The United Nations 2030 Agenda for Sustainable Development (UN 2016) highlighted a significant role for businesses to address wide-ranging Sustainable Development Goals (SDGs) to end poverty, fight inequality and injustice, and tackle climate change (Sachs 2012; Muff, Kapalka, and Dyllick 2017). Some business schools have been in the spotlight for their reticence in foregrounding sustainability in their curriculum (Doh and Tashman 2014) and studies have concluded that embedding is challenged due to a lack of systemic and institutional approaches (Painter-Morland et al. 2016). Some scholars have directly attributed management education's poor record in 
developing wider skills and capabilities to deficits in integration of sustainability principles into business and management courses (Waddock and Lozano 2013). Business graduates are faced with addressing sustainability-related issues and this presents business schools an opportunity to develop curricula that includes sustainability issues and discourses. These can include concerns about income inequities, food security, ecosystem decline and climate change, delivered in a way that appears relevant to academic disciplines and students.

Sustainability learning as an educational rationale, is an approach that considers how humans can manage and interact with the total socio-ecological systems of which they are a part (Hansmann 2010). In higher education, the challenge for sustainability is to approach learning through an integrative framework established across disciplines such as science, social science and managerial science (Dieleman and Huisingh 2006). Buckler and Creech (2014) similarly identified disciplinary boundaries as barriers to exploration of complex sustainability issues, while acknowledging that 'built in' approaches, whereby sustainability is embedded across programmes, serve a broader purpose than 'bolt on' offerings (120). Interdisciplinarity has been identified as one of the 'greater goods' and biggest challenges (Reid 2019) whereby coordinated efforts to integrate across disciplines have been restricted by resistance that is amplified by concerns regarding legitimacy and where the locus of the field should reside (Bursztyn and Drummond 2014). Within the business curriculum, the challenge is not only one of integrating, but also how and where sustainability should be embedded within curricula. Sustainability learning can occur through a variety of pedagogical approaches, ranging from a holistic pedagogy (Shrivastava 2010; Warburton 2003), drawing on knowledge from across a broad range of disciplines (Benn, Edwards, and Angus-Leppan 2013) to a disciplinary-based pedagogy, raised as an issue or topic within a disciplinary field.

Making sense of sustainability as a construct is complex and subject to ongoing scientific debate; it can "be approached from different levels of reference, in time, space and from environmental, social and economic perspectives" (Zaman and Goschin 2010, 6). Despite this and its disciplinary pluralism, sustainability must be embedded within existing disciplines and 'translated' into diverse pedagogies of individual educators (Birdsall 2015). Accordingly, a conceptual understanding of sustainability that is both malleable enough to be fragmented and interpreted specifically within disciplines, yet coherent enough to be holistically understood across them, should facilitate embedding sustainability across business disciplinary areas such as management, accounting, marketing and finance that comprise most business school curricula.

Yet even despite institutional pressure from business school accreditation bodies to assure sustainability learning (AACSB 2013), barriers have impeded the development of integrative and holistic approaches, such that most are neither coherent, nor institutionalized (Doh and Tashman 2014). This paper outlines one business school's process to overcome these challenges to integrate and embed sustainability into business school curricula through a participatory process assisted by the use of boundary objects. Boundary objects have the potential to facilitate dialogue among people with significantly different world views. Boundary objects are artefacts, documents, terms, concepts and other forms of reification which make ideas more concrete. They reside between disciplines, are ill-structured, and are a set of work arrangements that are 'at once material and processual' (Star 2010, 604). They have been studied in the context of learning for sustainability as enablers for shared sense making in 'Communities of Practice' (Benn, Edwards, and Angus-Leppan 2013; Benn and Martin 2010) and as attractors to mediate learning between organisational communities (Macpherson and Jones 2008). Hawkins, Pye, and Correia (2017) highlight that mutable boundary objects play an important role in facilitating learning about what is included within a certain sustainability discourse and that which is discounted.

A related research objective was to explore how participatory processes could bring academics together to develop a coherent sustainability discourse and a learning objective that would span across, and be relevant within, each of the different business disciplines. Reid (2019) 
concluded that such forms of research involving people provide a foundation for knowing about an area of inquiry by inclusive, open and ethical means. Adopting a Participatory Action Research (PAR) (Kemmis and McTaggart 2005) process, this study analysed these processes of developing and embedding sustainability in the curriculum of a large Australian business school by including people who were engaged in that curriculum development process. The PAR shaped both the process that guided the research study and the methodology through which the findings in this paper are synthesised. Through reflexive phases of research and action, the authors both created the research and were the objects of study in the research. They both created and studied the curriculum development process, their role in it and the boundary objects that emerged from and enabled process. Therefore in this paper we address the research question: how do boundary objects and participatory processes between academics and other professionals interact to embed sustainability learning within and across business curricula?

\section{Embedding sustainability in business curricula}

Sustainability in higher education business school curricula is often defined within a narrow 'profit oriented' business discourse (Andersson and Öhman 2016). In such an approach, sustainability may be integrated into business curriculum merely as a stand-alone topic within a discipline, translated as just another mechanism for obtaining profits or as an issue of efficient management. A more holistic embedding approach can expose business curricula to diverse discourses, or what Andersson and Öhman (2016) define as 'social-oriented' or 'radical-oriented' logics. In the former, business can be understood as having a purpose to pursue social and environmental objectives with the same priority as profit generation, or in the later the business is founded on promoting sustainability (Andersson and Öhman 2016). Such approaches align with a perspective that sustainability should be embedded into the foundation of business curricula. Neglecting sustainability as a holistic concept or dismissing differing discourses may restrict the abilities of graduates from Business Schools to engage with complex sustainability challenges. This presents a challenge for traditional business curricula, that is usually siloed within disciplines that originate from a narrow profit-oriented business discourse that is separated from socio-ecological systems.

Sustainability provides a means for bridging across business disciplines and between business and other disciplines such as science, design and the humanities and hence developing curricula that is multifaceted and that engages with the complexity of socio-ecological issues through multidisciplinary (Tress, Tress, and Fry 2005), interdisciplinary (Turner et al. 2015) or transdisciplinary approaches (Max-Neef 2005, 15). Sustainability curriculum could develop through a: (i) multidisciplinary approach where participants work within their discipline-specific perspectives with the goal of combining knowledge in a sequential manner; through an (ii) interdisciplinary approach, where participants from different disciplines collaborate to co-create curriculum, which remains rooted within their own disciplines; or through (iii) transdisciplinary approaches where participants from diverse disciplines collaborate together and with other non-disciplinary experts to dissolve boundaries between disciplines and construct meaning in the context of real-world problems or themes. What is common to each approach is that they bring disciplines together to develop ways of knowing that draw from within, across or transcending disciplines and they are therefore reliant on participatory processes to enable interactions between disciplines.

Within and among business disciplines there is considerable debate regarding how and to what extent sustainability should be integrated or embedded. In the management discipline for example, Rusinko (2010) classified the wide range of approaches using a matrix where sustainability is integrated into curriculum according to the focus of integration (ranging from narrow and disciplinary specific to broad and cross-disciplinary) and the type of delivery (ranging from built in to existing structures through to developed into new structures). Page and Collins (2010) 
demonstrated how integration is often limited to a major or specialization. Others argue that embedding through frameworks such as the Principles for Responsible Management Education (PRME) and the SDGs requires a paradigm shift such that business education pursues a moral purpose (Louw 2015; Waddock et al. 2010; Rasche and Escudero 2010) and by engaging with authentic and experiential learning techniques (Dean, Gibbons, and Perkiss 2019). Starik et al. (2010) have concluded that sustainability in management education requires a 'transformative' and holistic approach, integrated across the core knowledge base by embedding business within systems thinking (Porter and Córdoba 2009). Vastly different approaches have been taken to integrate sustainability in business school curricula and few studies have examined the transdisciplinary processes of curriculum design (Clark and Button 2011; Onuki and Mino 2009).

\section{Boundary objects as attractors and enablers}

Where different interpretations and approaches to sustainability occur across disciplines, researchers have highlighted the importance of boundary objects that facilitate knowledge sharing between different social worlds (Star and Griesemer 1989). As defined earlier, boundary objects are both process oriented and material and they act as attractors to mediate learning between different perspectives. This then facilitates coordination without consensus (Bechky 2003; Star 2010), such as that required for different actors or groups or stakeholders to work together across disciplinary boundaries. It has been claimed that these boundary objects enable actors from different disciplinary or role-based backgrounds to collaborate more effectively around environmental and social dimensions of sustainability (Benn and Martin 2010) and to better facilitate sustainability learning (Benn, Edwards, and Angus-Leppan 2013).

Boundary objects manifest themselves in different forms; they can be: repositories containing classification schemes; artefacts or 'road maps' in the form of made things such as visual representations or diagrams; standardized forms devised to enable common communication across work groups; or coincident boundary objects, being common objects that have different internal contents in different contexts (Star and Griesemer 1989). The key functional point of boundary objects is that they have one objective manifestation, either physical or conceptual, but this manifestation is interpreted differently by different actors (Gal, Lyytinen, and Yoo 2008) within a group, network, work unit or in a community of practice (Wenger 1998) hence providing a means for members to organize their interconnections.

Star (2010) argues that researchers often overlook how boundary objects enable people to interact without consensus and even when the point of their interaction is contestation (Star 2010). When people interact, they tend to focus on what matters to them and accordingly they negotiate, contest and translate meaning in their own way. What really makes something a boundary object is that people keep 'tacking back and forth' and renegotiating its meaning (Star 2010). Boundary objects attract people to one another, despite their differences (Hawkins, Pye, and Correia 2017) and they then continue to renegotiate their own diverse translations of the object as they discuss, contest and negotiate their differences. As soon as people come into agreement and alignment that particular concept or material manifestation ceases to become a boundary object (Hawkins, Pye, and Correia 2017).

\section{Research approach}

Following an empirical approach similar to Akrivou and Bradbury-Huang (2015), we adopted an 'insider-out' understanding of a university setting, where embedding sustainability in the business curriculum was conceptualised as an evolutionary and co-created process occurring between and within disciplines. Our study was located within a business school in an Australian university during and after a review the undergraduate teaching program. It was undertaken at a 
time when senior management determined that sustainability (along with ethics and creativity) would be a core theme embedded across all of the business school curricula. As part of the commitment, a new subject called 'Integrating Business Perspectives' (IBP) was to be introduced into the Bachelor of Business as a compulsory core subject which would introduce this and other key themes.

From the outset, the Associate Dean of Teaching and Learning (ADTL) initiated a curriculum development approach that encompassed both a strategic top-down process and a collegiate participatory process. The strategic process outlined that sustainability would be a key concept in the redesign of the business school curricula. This was further legitimized through a professional accreditation body (the Association to Advance Collegiate Schools of Business - AACSB) acknowledging sustainability as a key learning objective. The participatory process was enabled through the establishment of a sustainability working party comprising academics from each of the disciplinary areas in the Business School and teaching and learning specialists. The sustainability working party included thirteen academics representing the disciplines in the business school (marketing, management, accounting, finance, economics), the ADTL, two sustainable business researchers and two teaching and learning professionals. The appointed Chair was the faculty Professor of Sustainable Enterprise.

In the Participatory Action Research (PAR) approach the researchers are also the key actors in the design, implementation and review cycles of the process. Participatory action researchers (e.g. Kemmis and McTaggart 2005; Reason \& Bradbury 2006) argue that participatory inquiry and practice can generate transformational organizational change. Each researcher is also a participant, engaged in facilitating change in the teaching and learning practices to integrate sustainability in and throughout the business curriculum. This includes introducing sustainability as an area of research emphasis as well as curriculum development. The researchers could mostly be described as having a proactive orientation toward sustainability teaching, learning and research as many were already actively applying and championing sustainability in these aspects of their professional work.

These sustainability working party participants were a community of practice. They engaged in a developmental process which was documented over a seven-year period utilizing PAR to enable an evolutionary curriculum development process. The PAR evolved over four different stages and involved sustainability working party monthly meetings where participants engaged in open dialogue, debate, collective reflection and collaborative planning to develop an approach to integrate sustainability across their disciplines and embed it within the redesigned curricula. During the first and second stages of the PAR, several sustainability working party participants were less proactive about sustainability in business, and took a more critical stance, providing a judicious perspective that prompted the group to further contest, debate and refine the sustainability discourse. Boundary objects were developed to help facilitate that contestation and debate, such as possible definitions of sustainability.

In between meetings, 'co-learning' activities were implemented by sustainability working party participants to include participants (other academics) from the business school and other faculties including Environmental Science, Design and Arts and Social Sciences. This included consultation, dialogue and interviews with individual subject coordinators and those responsible for translating sustainability into their disciplinary subjects. Sustainability working party participants shared and stored curriculum development documentation in a restricted online file sharing system (to adhere to ethical procedures) and shared artefacts through an open access repository (www.sustainability.edu.au). Data was collected in the form of interviews, meeting minutes, discussion and strategy documents, surveys and focus groups, throughout the various PAR cycles to evaluate, reflect and inform the next cycle of inquiry.

Through the PAR approach, the 'knower' (in this case the sustainability working party participants and other participants engaged in the process of developing and embedding sustainability) participates in four ways of knowing being experiential, presentational, propositional, and 
practical. Experiential knowing involves face to face encounters that are participative and empathetic; presentational knowing or co-learning occurs through the use of expressive or aesthetic forms of imagery; propositional knowing is at the level of conceptual development; and, practical knowing is the 'how' of knowing expressed as a skill or competence (Heron and Reason 2006). The PAR is a form of cooperative inquiry that is established through these epistemological cycles by deliberate phases of reflection and action, with the result that the research matters to the participants as a practical concern and is thus a means of bringing about change. The PAR thus complements evolutionary curriculum development and the ongoing cycles of cooperative inquiry enable reflective interaction between disciplines that can allow new interpretations and approaches about sustainability to emerge within and across disciplines.

\section{Data collection and analysis}

PAR involved sustainability working party monthly meetings to engage in open dialogue, collective reflection and collaborative planning. Between meetings, co-learning activities were implemented by sustainability working party members in collaboration with faculty members, students and external stakeholders. Sustainability working party members shared and stored documentation in an online file sharing system. Documentation was regularly added to this file share including meeting minutes, discussion and strategy documents, accreditation data and evaluation reports, samples of teaching and learning materials, and published reports and academic papers. All this served as an ongoing data collection repository to track the development of the process.

In addition, several data collection points were planned. Data was collected through the form of interviews, surveys and focus groups. This data was stored securely in a separate file with limited access to adhere to ethical procedures. Data were collected from the sustainability working party members and the other academics, professionals and students who participated in different parts of the process during the various cycles of inquiry to evaluate, reflect and inform the next cycle of inquiry. Each part of the process therefore provided valuable learnings and outcomes that were used to inform subsequent processes.

In analysing the data, the researchers were interested in both the outcomes of the process and the processes that enabled the outcomes. Boundary objects were deliberately analysed as both tools and outcomes. In this way the objects enabled sustainability working party participants and others to discuss and debate the meaning and at the same time they were co-created through the collaborative input, debate and dialogue between the participants. They therefore became outcomes of and inputs to the various iterative cycles to enable knowing to be translated across disciplinary boundaries.

\section{Findings and discussion}

In the following we report on the major findings derived from analysis of the PAR and discuss the relevance of each in relation to the process of sustainability curriculum development. Due to the nature of the PAR, the findings in each stage became the focus of reflection and discussion within the next PAR stage, which in turn resulted in further initiatives to embed sustainability in the curriculum. The findings of the research and discussion of these findings are therefore inextricably linked.

The major findings include firstly, that a broad cross-faculty participatory curriculum development processes can enable sustainability to be embedded in a business school curriculum. The character of these development processes evolved cyclically and categorically changed in each curriculum development stage as shown in Table 1 in the next section. Secondly, the PAR revealed that different boundary objects were both significant and productive not only in facilitating debate and contesting ideas and interpretations of sustainability within the PAR, but also 
Table 1. Stages in the curriculum development process by type of disciplinary interactions, activities and outcomes.

\begin{tabular}{|c|c|c|c|}
\hline $\begin{array}{l}\text { Curriculum Development } \\
\text { Cycle and Aim }\end{array}$ & $\begin{array}{l}\text { Disciplinary } \\
\text { Interactions }\end{array}$ & $\begin{array}{l}\text { Sustainability Working Party } \\
\text { Members Key Activities }\end{array}$ & Key Outcomes \\
\hline $\begin{array}{l}\text { 1. Development: understand } \\
\text { current positioning of } \\
\text { sustainability logic in } \\
\text { each discipline }\end{array}$ & Multidisciplinary & $\begin{array}{l}\text { Survey of subject documents } \\
\text { to discover the presence } \\
\text { of sustainability logic. } \\
\text { Infrequent sustainability } \\
\text { working party meetings - } \\
\text { not formalised. }\end{array}$ & $\begin{array}{l}\text { Interim report on sustainability } \\
\text { in curriculum by disparate } \\
\text { disciplines. } \\
\text { Generic sustainability definition } \\
\text { - Brundtland commission. } \\
\text { Sustainability determined to be } \\
\text { a 'key theme' in B.Bus } \\
\text { review and be the } \\
\text { foundation of a new core } \\
\text { subject called Integrating } \\
\text { Business Perspectives (IBP). }\end{array}$ \\
\hline $\begin{array}{l}\text { 2. Design: create and } \\
\text { consolidate approaches } \\
\text { to sustainability across } \\
\text { the program }\end{array}$ & Multidisciplinary & $\begin{array}{l}\text { Focus groups and interviews } \\
\text { within disciplines and } \\
\text { feedback at monthly } \\
\text { sustainability working } \\
\text { party meetings. }\end{array}$ & $\begin{array}{l}\text { An initial sustainability } \\
\text { Program Learning Objective } \\
\text { (PLOv1) as a standard form. } \\
\text { Appointed a Chair in } \\
\text { Sustainable Enterprise in } \\
\text { Business School and as } \\
\text { chair of sustainability } \\
\text { working party. } \\
\text { Repository of learning materials } \\
\text { (powerpoint slides, } \\
\text { assessment questions). }\end{array}$ \\
\hline $\begin{array}{l}\text { 3. Implementation: create } \\
\text { nuanced applications } \\
\text { within disciplines and } \\
\text { overcome } \\
\text { integration barriers }\end{array}$ & Interdisciplinary & $\begin{array}{l}\text { Consult with subject } \\
\text { coordinators to develop } \\
\text { learning materials. } \\
\text { Interviews with coordinators } \\
\text { to detect barriers. }\end{array}$ & $\begin{array}{l}\text { Report on outcomes of } \\
\text { implementation. } \\
\text { Repository of learning } \\
\text { materials (powerpoint slides, } \\
\text { assessment questions). } \\
\text { Identification of } \\
\text { implementation barriers as } \\
\text { decision making problems } \\
\text { and context/value } \\
\text { laden problems. }\end{array}$ \\
\hline $\begin{array}{l}\text { 4. Renew: develop an } \\
\text { evolving learning } \\
\text { approach to sustainability }\end{array}$ & $\begin{array}{l}\text { Multidisciplinary } \\
\text { moving towards } \\
\text { transdisciplinary }\end{array}$ & $\begin{array}{l}\text { Full day retreat to transcend } \\
\text { disciplines. }\end{array}$ & $\begin{array}{l}\text { New contextualised definition } \\
\text { of sustainability in business. } \\
\text { PLO v2 at levels of learning. } \\
\text { Multidisciplinary case studies. }\end{array}$ \\
\hline
\end{tabular}

between and within disciplines. A wide variety of boundary objects contributed to the process and enabled different ways of knowing (a summary overview of these is provided later in Table 2). One of the most important boundary objects was the co-created, Program Learning Objective version 2 (PLOv2). This coincident boundary object was malleable enough to be translated into different disciplinary contexts. Thirdly, the institutional context provided support and legitimacy for the embedding of sustainability in the curriculum. This legitimacy was not just based on endorsement from the leadership of the business school but also through the dispersed leadership of the sustainability working party participants through the PAR. We now elaborate each of these in turn.

\section{Participatory curriculum development process}

We depict the curriculum development processes as it evolved through 4 distinct stages in the timeline in Figure 1 (below). This figure also features productive boundary objects that facilitated and emerged from the process which are discussed in more detail in the next section.

Within each of these stages the participants engaged in the PAR cycles through various different activities. All throughout they engaged in monthly face-to-face encounters where experiential knowledge was a key feature. The presentational knowing is grounded in, and emerges from, 
Table 2. Examples of productive boundary objects by type.

\begin{tabular}{lcc}
\hline Boundary Object & Boundary Object (material/ & \\
Manifestation (type) & aesthetic form) & Description \\
\hline
\end{tabular}

Sustainability definition
and principles

PLOv2

Multidisciplinary case studies

Logic of sustainability in business

Wicked problems case studies

Artefact

Sustainability as a core 'theme' in the Business degree

Energy Efficiency

Disciplinary based lecture slides

The Nested Sustainability Systems Model

\section{Standardised form}

Repository

Program Learning Objective (PLOv1)

Surveys of sustainability content

www.sustainability.edu.au

Intranet drive

\section{Classification Scheme}

\author{
Scheme of defining \\ sustainability issues
}

Survey template
The agreed definition of sustainability in the business school changed over time. It started as being a commonly accepted Brundtland Commission definition and morphed to be more specific within the context of the business disciplines. The revised version featured the prioritisation of stakeholders and included decision making and responsibility as core features.

A malleable learning objective that could be assured at different learning levels and by discipline - See Table 5

Case studies with a sustainability focus which could be used across various disciplines.

Report outlining how sustainability is interpreted within the various disciplines.

Co-developed by participants on topics such as climate change and sustainable consumption that were implemented in the foundation business subject. See for example: http://sustainability.edu.au/material/ teaching-materials/carbon-wicked-problem/.

Materialised as a figure (see Figure 2), and was also articulated as being and core graduate attribute in undergraduate teaching program.

Was developed as a key competency and learning module particularly within the accounting disciplines and in collaboration with Accounting professionals see for example: http://sustainability.edu.au/aboutsustainability/energy-efficiency/.

Participants developed lecture slides in collaboration with other subject coordinators that were used in lectures to define sustainability within the differing disciplines.

Facilitated broad discussion within and across the disciplines regarding which model was the best representation of business in relation to society and ecology. This was introduced to students in their first year foundation subject IBP as a contested object (see Figure 3).

See table 4. This was used as a compliance tool to ensure subject coordinators were embedding sustainability within their disciplinary based subjects.

A pro forma used for documenting sustainability content in subjects (See Table 3).

An open access website repository where academics can share and co-create learning modules and teaching material artefacts. Participant contributed teaching materials that could be freely accessed for example http://sustainability.edu.au/material/ teaching-materials/by-institution/university-oftechnology-sydney/.

Shared resources included a wide range of teaching support material to embed sustainability in the curriculum made available to all academics.

This scheme was used as the architecture for classifying materials by issue and discipline within the online repository.

A list of questions to probe for insights regarding what sustainability means within the discipline, how it is represented within the teaching programs and how is learning assured. Used for interviews with Heads of Disciplines and disciplinary academics. Outcomes fed back into the discussion of the Sustainability working party to formulate the PLO 


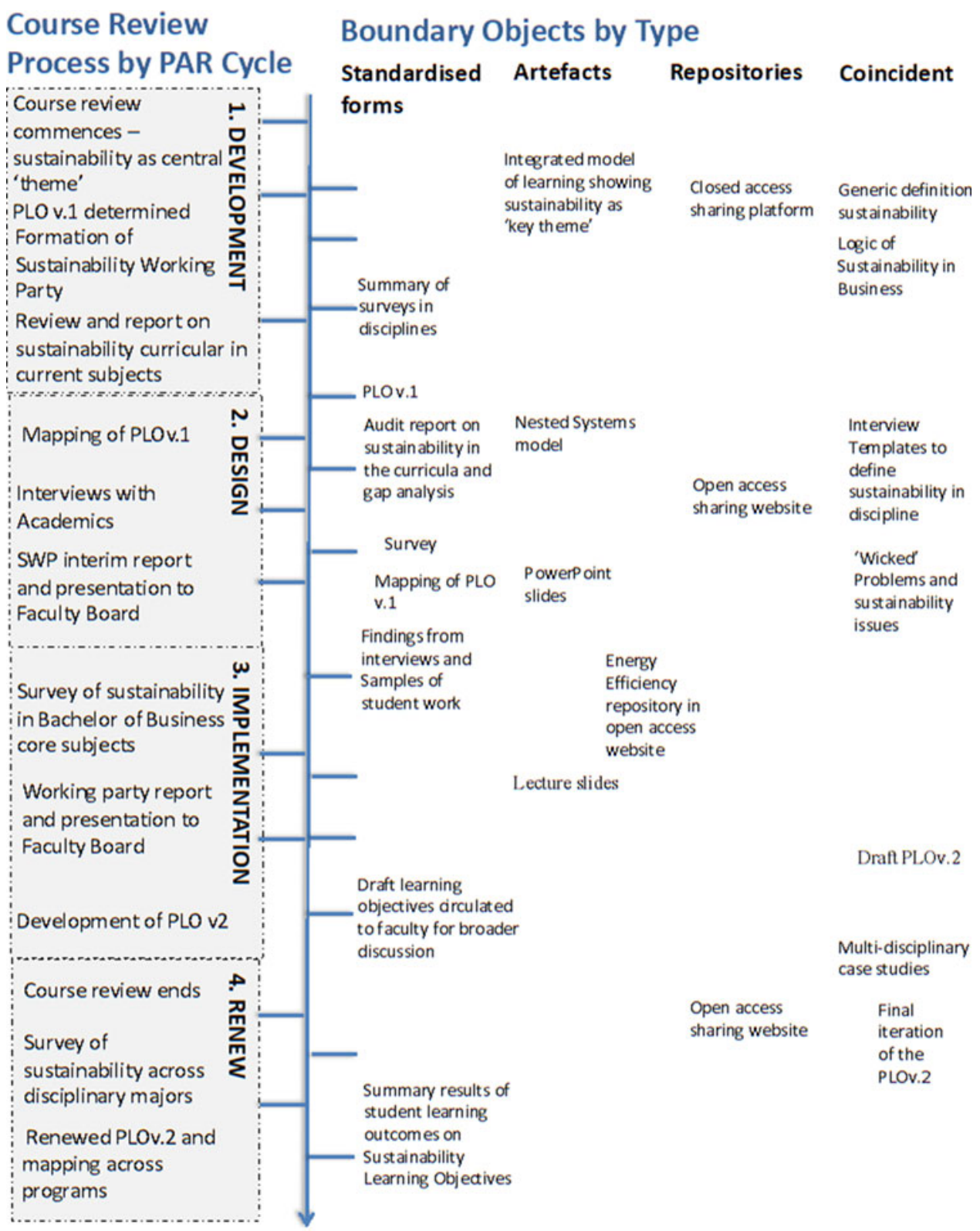

Figure 1. Timeline of the PAR and boundary objects by type.

the experiential knowing. The later came through the ability of participants to co-generate knowing by presenting their interpretations about sustainability to one another and their peers across their disciplinary boundaries. Through this form of ongoing participation, they came to identify which presentational artefacts allowed meaning to translate across their disciplines or transgressed beyond so they found agreement between their disciplines. These became propositional forms of knowing which were then shared more broadly with other participants in their disciplines. So the activities of the sustainability working party changed in each stage and as they developed propositional and practical ways of knowing that manifested as boundary objects, such as models, Program Learning Objectives (PLOs) and sustainability teaching materials. By engaging in ongoing experiential learning they moved towards more collaborative forms of 
disciplinary interactions. Table 1 (below) provides an overview of the development stages, the key activities undertaken by the sustainability working party participants and the forms of disciplinary interactions.

There was a distinct evolution in the character of the sustainability working party participant activities. In the 'development' stage, participants shared their various ways of knowing about sustainability from their individual business disciplinary silos. Their meetings were infrequent and interpretations of sustainability in within their disciplines were disparate. Through the PAR cycles that engaged participants in ongoing dialogue and debate, the interactions between their disciplines progressed towards becoming multidisciplinary or at times transdisciplinary as participants came to understand points of divergence and convergence between their disciplines. They also developed ways of communicating and translating meaning across disciplines.

After several stages, in the fourth 'renew' stage, they had progressed to multidisciplinary interactions where the different approaches to and views of sustainability converged as a PLOv2 across and within disciplines. In this final stage there were instances of transdisciplinarity, mainly across the business disciplines, where participants engaged with a problem context and addressed it from outside their disciplinary base. Two meetings enabled 'beyond business' interactions when participants were included in the development of teaching materials and new course programs from other non-business disciplines such as Environmental Science, Design and the Humanities. In other instances, there were interactions between academics and other professionals in a transdisciplinary arrangement, especially in relation to the Energy Efficiency concept and knowledge repository.

\section{Productive boundary objects}

Within each stage and the various PAR cycles, different boundary objects were identified as having a significant role in bringing participants together to debate and contest ideas about and interpretations of sustainability. This coming together is a feature that signifies a productive boundary object. 'Productive' means that the objects were focal points and attracted discussion and participation enabling academics to 'tack back and forth' to makes sense of sustainability. They act as sources of attraction that generate dialogue and debate between and within disciplines. Table 2 (below), provides a descriptive overview of boundary object manifestations and in the following discussion we highlight the process through which various objects emerged through the PAR. Through various different disciplinary interactions, objects were co-created by the sustainability working party and other subject coordinators so that they could loosely coordinate their local actions to integrate sustainability with some coherence across the Business disciplines. These were both created as outcomes by, and were generative of, the participatory process.

Co-generation of knowledge about sustainability was assisted by various boundary objects. For example, sustainability working party participants compiled several reports to inform the curriculum development process. Presentational knowing was important during the first stage of the PAR as participants attempted to communicate what sustainability meant in their disciplines. Initially they adopted the generally accepted sustainability definition derived from the United Nations Brundtland Commission report. Participants explained their interpretation of sustainability from each discipline group and proposed recommendations. In this first report, the disciplinary views were highly disparate. For example, the Finance group stated that their primary concern was maximisation of firm value and that sustainability would be considered discretionally and as a broader objective if necessary. Whereas accounting stated they would consider a stakeholder view alongside the shareholder view.

This report, therefore, acted as a boundary object based on which academics from each discipline could communicate their own way of knowing about sustainability and its significance 
Table 3. Review of sustainability content in subjects in the marketing major.

\begin{tabular}{|c|c|c|c|}
\hline \multirow[b]{2}{*}{ Subject } & \multicolumn{3}{|c|}{ Pro-Forma for Major: Marketing } \\
\hline & $\begin{array}{l}\text { Relevant Subject } \\
\text { Learning Objectives }\end{array}$ & $\begin{array}{l}\text { Amount of identified } \\
\text { Sustainability content }\end{array}$ & $\begin{array}{l}\text { Identified as Adequate } \\
\text { or Need for Review }\end{array}$ \\
\hline $\begin{array}{l}\text { Customer } \\
\text { Behaviour }\end{array}$ & $\begin{array}{l}\text { - Explain theoretical foundations of } \\
\text { customer behaviour \& customer } \\
\text { experiences. } \\
\text { Apply customer behaviour } \\
\text { theories, frameworks and } \\
\text { concepts to managerial marketing } \\
\text { decision contexts. }\end{array}$ & $\mathrm{Nil}$ & $\begin{array}{l}\text { Review Needed - persuasion to } \\
\text { consume, planned obsolescence, } \\
\text { status consumption and } \\
\text { sustainable consumption should } \\
\text { be covered. }\end{array}$ \\
\hline $\begin{array}{l}\text { Business } \\
\text { Marketing } \\
\text { Analysis \& } \\
\text { Strategy }\end{array}$ & $\begin{array}{l}\text { Implement practical solutions to } \\
\text { complex business } \\
\text { marketing problems } \\
\text { Apply business marketing } \\
\text { theories, frameworks and } \\
\text { concepts to managerial } \\
\text { decision contexts } \\
\text { - Apply analytical perspectives and } \\
\text { decision tools, which underlie } \\
\text { creative business marketing } \\
\text { decisions }\end{array}$ & Nil & $\begin{array}{l}\text { Cradle-to-cradle, bio-mimicry, } \\
\text { closed-loop systems should } \\
\text { be included. }\end{array}$ \\
\hline
\end{tabular}

within their discipline. Two disciplines, finance and marketing, noted a 'lack of acceptance' within their discipline and a 'peripheral' treatment of sustainability as an incidental topic or case study, thereby both acknowledging and dismissing sustainability. This report became a point of attraction for the sustainability working party participants and their colleagues as they discussed the disparities between the interpretations and the extent to which each discipline had included sustainability as a foundation or peripheral concept. This signified the importance of sustainability in the business school; it did not, however, provide a coherent discourse for understanding sustainability across and within the business curriculum.

In the second stage they produced an interim report, one of the inputs to this report was the output of sustainability working party participants surveying academics in their disciplines to determine how sustainability content was included or excluded in curriculum (an example of the form used for this process in the Marketing Major is shown in Table 3, below).

They used a 'pro forma', a standard form boundary object to survey and present how sustainability concepts were currently represented within compulsory subjects in each disciplinary major within the undergraduate degree. The Chair guided participants to use the pro forma to generate a review "that should not comply with the political and social construction of reality of any one School, but rather be mindful that successful organisation change requires negotiation and that our review should be helpful and informative for the various subject coordinators". These consultations instigated much debate and dialogue between participants as to what should or should not be classified as 'sustainability content' and what should be recommended going forward. This survey therefore acted as boundary object and was productive in helping to enable the various cycles of experiential and presentational knowing. From this also arose another boundary object in the form of the PLOv1 and definition (see Table 4) and an artefact boundary object in the form of model (see Figure 2, below) that depicted 'sustainability' as a core theme in the revised foundation subjects for the Bachelor of Business.

This model attracted much discussion regarding how these themes would be interpreted and positioned within and across the disciplinary subjects, Subsequentially, a more prescriptive and unidimensional PLOv1 was developed and it resembled a standard form boundary object. It was designed to be a compliance based tool that relegated sustainability as a sub-objective and optional context for the application of critical thinking. During this stage and because there was a lack of common understanding between the participants, they continued to use the generally 
Table 4. Initial sustainability definition and PLOv1.

\section{Definition of Sustainability}

The United Nations definition of sustainable development that is known as the Brundtland definition:

Sustainable development is development that meets the needs of the present without compromising the ability of future generations to meet their own needs.

Program Learning Objective 4- Have an awareness of obligations and responsibilities in business and their impact Of which a sub-objective is:

Critically analyse the core professional obligations, values and operations of organisations, including sustainability

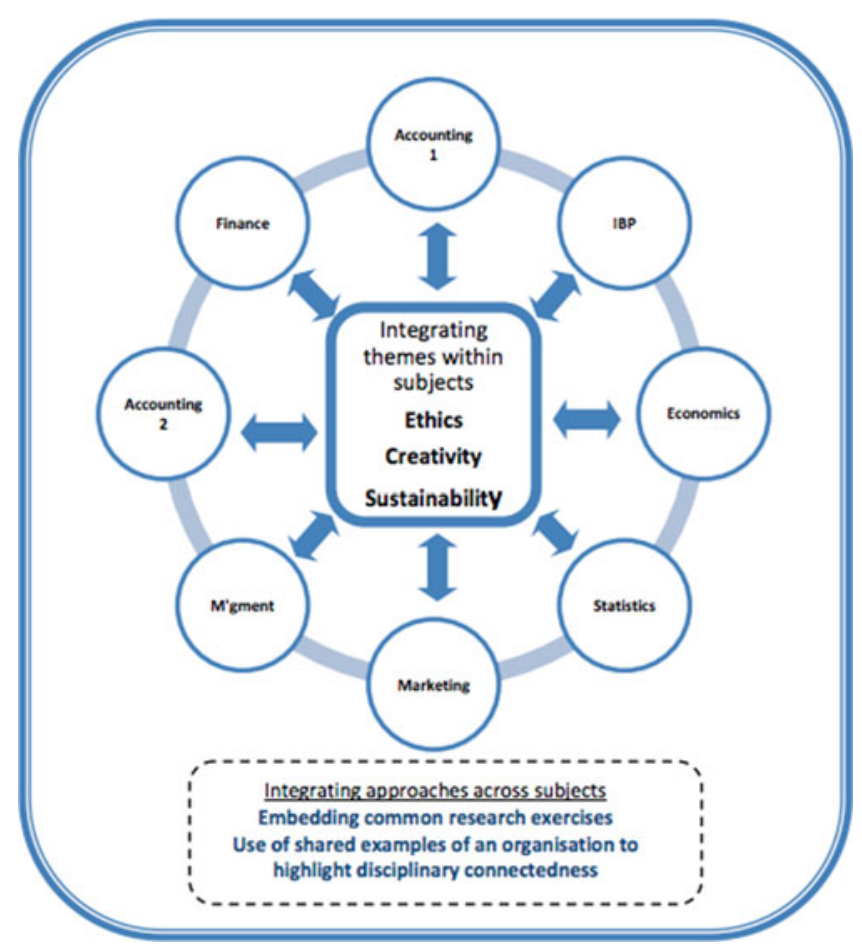

Figure 2. Example boundary object: sustainability as a key theme.

accepted definition derived from the United Nations Brundtland Commission report (see Table 4 for a summary).

As the participants were tasked with designing and implementing sustainability in the curriculum, coincident boundary objects, such as maps, principles, definitions and wicked problems, were productive for facilitating cycles of experiential and propositional knowing. These objects were productive because they engaged participants in discussions and focussed attention on addressing a shared sustainability issue or problem. Sustainability working party participants created and shared multi-disciplinary case studies about sustainability issues and 'wicked problem' case studies that focussed on problems such as climate change, waste and sustainable consumption. This moved the whole community away from the typical academic tradition where practical knowing can constrain participants within their disciplinary silos as they seek to reinforce particular disciplinary epistemic objects and disciplinary ways of learning and knowing.

As well as being material outcomes, the boundary objects were also generative of the PAR processes as they helped to enable cooperative inquiry. As participants engaged with these boundary objects, this often facilitated a change in their ways of knowing or understanding about sustainability. This often had an iterative effect in evolving the form and content of the boundary object and on how sustainability became embedded in the evolving curricula. For example, an ongoing discussion between sustainability working party participants and other 


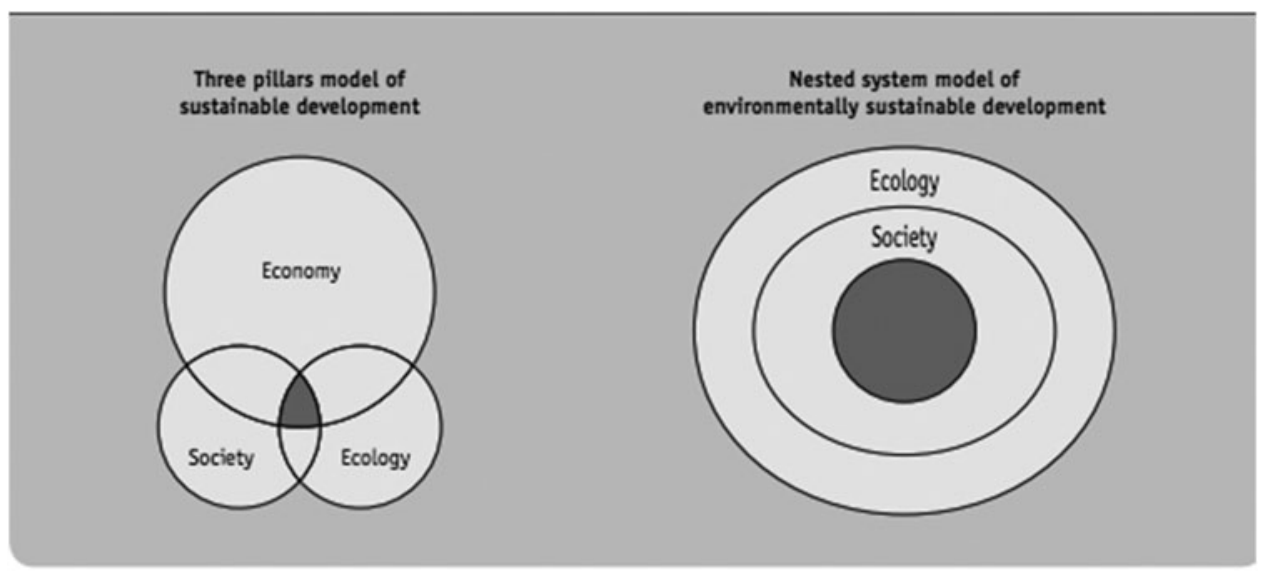

Seucre: Adapted from Awtralia: Statt of the Environment 1996, An Independent Report Presented to the Commonwealth Minister for the Environment by the State of the Environment Advisory Council, Chapter 10.

Figure 3. Example boundary object: the nested sustainability model.

Source: Adapted from Australia: State of the Environment 1996, An Independent Report Presented to the Commonwealth Minister for the Environment by the State of the Environment Advisory Council, Chapter 10.

Table 5. Reworked definition and PLOv2.

\section{Definition of Sustainability}

XXX Business School understands sustainability as referring to the long term, to the concept that decisions made now should not impair the quality of life for future generations. They should not erode our stores of either natural or human capital. A fully sustainable business operates to maintain and restore stocks of natural resources and to improve human and societal wellbeing

\begin{tabular}{|c|c|c|}
\hline Expose & Engage & Immerse \\
\hline $\begin{array}{l}\text { Students are treated primarily as an } \\
\text { audience and are provided with a } \\
\text { broad awareness of origins and } \\
\text { content related to this } \\
\text { essential knowledge. }\end{array}$ & $\begin{array}{l}\text { Students begin to learn and develop the } \\
\text { skills needed to explore diverse } \\
\text { dimensions of this } \\
\text { essential knowledge. }\end{array}$ & $\begin{array}{l}\text { Students are a self-directed active } \\
\text { participant in identifying and } \\
\text { engaging in opportunities to discern } \\
\text { variety and distinctions (in order to } \\
\text { make professional-accountable } \\
\text { judgments) regarding the application } \\
\text { of this essential knowledge. }\end{array}$ \\
\hline \multicolumn{3}{|c|}{$\begin{array}{l}\text { Sustainability PLOs - Undergraduate. } \\
4.2 \text { - Critically analyse sustainability principles for various stakeholders in relation to business contexts. }\end{array}$} \\
\hline $\begin{array}{l}\text { Demonstrate an awareness of } \\
\text { sustainability principles in relation to } \\
\text { a business context. }\end{array}$ & $\begin{array}{l}\text { Evaluate sustainability principles as they } \\
\text { apply to various stakeholders. }\end{array}$ & $\begin{array}{l}\text { Make, defend \& be accountable for } \\
\text { professional judgments concerning } \\
\text { sustainability principles as they relate } \\
\text { to various stakeholders within a } \\
\text { business context. }\end{array}$ \\
\hline
\end{tabular}

participants within their respective disciplines centered on the conceptual positioning of the 'economy' in relation to 'society' and 'ecology'. The 'nested systems model' artefact (see Figure 3) catalysed these debates and discussions, and although not resolved, this artefact boundary object was generative and malleable as it allowed different interpretations of business sustainability to surface and be made explicit. The importance of this object is reflected in Appendix A.1, which was written by a member of the sustainability working party from the Management discipline. Figure 3 was introduced to students as an artefact when they were first exposed to sustainability in the new core subject, IBP. This artefact stimulated presentational ways of knowing as it simply represents fundamentally different conceptualisations of the relationship between business, society and ecology.

The progression towards transdisciplinarity, enabled through participatory processes, was fundamental to the emergence of an enhanced and more clearly elaborated PLOv2. This co-created PLO (see Table 5, below), is not prescriptive and as such is not a standard. It acts as a coincident 
boundary object as it articulates the broad terrain without being overly proscriptive. The PLOv2 clearly requires students to be able to 'Critically analyse sustainability principles for various stakeholders in relation to business contexts". It was designed so it could be interpreted differently within each of the disciplines and assured at different levels of depth (expose, engage, immerse). It aims to allow academics to grasp what is fundamental about sustainability within the business school curriculum. All of the participants in the PAR were of the view that this particular boundary object was important in facilitating the further embedding of sustainability in the curriculum (see also mention of this in Appendix A.1).

As a new propositional form of knowing, this PLOv2 encompasses a representation of how learners 'ought to' know across all business disciplines. As a coincident boundary object the content of the PLO allowed it to be malleable enough to be translated into different disciplinary contexts. As academics developed subjects and disciplinary-based majors shaped by this PLOv2, sustainability was dynamically translated, as a way of knowing at various levels. As a coincident boundary object, the PLOv2, was malleable so that at first the concept was introduced to students within their specific discipline (expose). At critical points they would then engage with it as a concept across business disciplines and drawing on science and other social sciences (engage). Finally, they may be immersed in taking an active role to apply their disciplinary knowledge to a sustainability context in a transdisciplinary process, often through a capstone subject. This PLOv2 signified sustainability learning as a core feature of the Business school curricula. Building on this ongoing dialogue about the importance of education for sustainability in business, the participants created a formalised stream within the undergraduate and postgraduate curricula in the form of a 'Sustainability and Responsible Management' sub-major. The undergraduate sub-major moved closer toward a multi-disciplinary approach as it comprised subjects from outside the business disciplines including a science (Biocomplexity) and a design (Design Futuring) subject.

Creation and use of boundary objects were particularly evident at the interfaces between the participants in the sustainability working party and as they engaged with their colleagues within and across disciplines. Nicolini, Mengis, and Swan (2012) proposed a similar notion when they noted that researchers need to consider more than 'what objects are used' but also 'when'. As the process moved between varied disciplinary interactions and PAR cycles, different combinations of different boundary object types were productive. However, it appears coincident boundary objects were most productive for experiential and propositional knowing, artefact boundary objects were most productive for contesting practical knowing, while standards and forms were most productive for practical knowing.

The study highlighted that disciplinary-based academics need to be encouraged to engage in practical knowing so that they can embed sustainability within curriculum. They also need to be supported and endorsed to that they can engage in ongoing and collective dialogue and debate. This means legitimising and institutionalising evolutionary curriculum development processes through presentational and experiential ways of knowing so academics can participate in encounters outside of their disciplinary boundaries and have co-learning experiences that help them develop new as well as refresh existing propositions.

Collegial interactions between participants from different and from within disciplines for the purpose of constructive curriculum development can also enable propositional and practical ways of knowing (Heron and Reason 1997) to eventually facilitate coherence in the form of a PLO boundary object. For example, through the PAR process, the initial resistance from the finance discipline group was overcome. This happened through ongoing dialogue and debates about where and how the sustainability PLO should be embedded in curricula and how might sustainability be defined within finance. This collegiate process was enabled by the coincident boundary object in the form of the PLOv2 and the catalytic actions of the sustainability working party participant as she went back and forth between her disciplinary based colleagues and the sustainability working party meetings (See Appendix A.2). Appendix A.2 was written by a 
member of the sustainability working party from Finance in the latter stages of the process following the development of reworked definition of sustainability and PLOv2. It illustrates the usefulness of boundary objects in facilitating discussions among Academics with diverse views.

This PLOv2 and definition was malleable enough so that individual subject coordinators could continuously contest how sustainability was interpreted through dialogue, debate and experiential and presentational ways of knowing. This facilitated deep discussion regarding how sustainability would be positioned in relation to the boundary object and how it would be integrated within the discipline. This form of curriculum development happened because of the ongoing interactions between the sustainability working party, a sufficiently diverse group of academics engaged in experiential ways of knowing focused on the aspirational goal of embedding sustainability in the curricula.

\section{Institutional features}

Finally, we identified an 'institutional' enabling function, created and legitimised by faculty leaders. These leaders formalised and endorsed the reports that contained the outputs of the PAR and they legitimized the PAR process as a form of curriculum development. That is, they permitted and gave recognition to participants to be engaged in the process, and consistently enriched it by drawing on the boundary objects and highlighting their significance as key learning objectives in the Business School. Thereby sustainability became recognized as a key feature of the curriculum development process through the symbolic legitimacy of the ADTL, the Chair of the sustainability working party and the Dean of the Business School as they connected outcomes from the sustainability working party with the AACSB accreditations. That is they demonstrated how sustainability had to be a significant feature of Business School curriculum to assure learning for strategic and accreditation purposes.

In turn this legitimization enabled the sustainability working party participants to engage in the participatory process and to attract other participants to take part. This was not a standalone function as legitimacy relied on the dispersed leadership enacted by the sustainability working party participants and recognition from their peers that the outcomes of the PAR processes in the form of boundary objects were productive in the development of curriculum. This institutional function allowed the legitimized sustainability in the form of coincident boundary object PLOv2, as previously discussed. Our research suggests that this 'institutional' enabling and legitimisation of the curriculum development process is necessary to provide continuity and coherence over time.

\section{Conclusion}

We began by asking how do boundary objects and participatory processes between academics and other professionals interact to embed sustainability learning within and across business curricula. We found that participatory and evolutionary curriculum development is possible when supportive institutional conditions are in place to enable dispersed leadership and permit the time and space required to engage in collegiate processes of dialogue and debate. Throughout the PAR process, sustainability learning evolved within the curriculum development process and in its various manifestations within the business school disciplines. At the commencement of the process, the approach by some business school academics to sustainability was predominantly 'profit maximisation' (Andersson and Ohman 2016), or in some disciplines it was dismissed, and sustainability was absent from the curricula. While the interpretation of sustainability that evolved through the PAR and materialised through the PLOv2 coincident boundary object does not equate with a 'social-oriented' or 'radical' perspective (Andersson and Ohman 2016); it is malleable so that academics may interpret it as such within their individual pedagogies. The 
participatory process enabled through the sustainability working party allowed and continues to enable the continuous evolution of such interpretations of sustainability.

This study indicates that the reflective multi- and transdisciplinary interactions between business academics developed from substantial prior interactions between disciplinary and nondisciplinary experts in the sustainability working party community of practice. The critical role and function of a community of practice has long been known (Wenger 1998), but it has not previously been a key feature of curriculum development processes in higher education institutions. Many of these have moved towards compliance based approaches in recent years. The PAR model in this study demonstrates that a community of practice has a productive role and function as a feature of curriculum development, because it supports academics to engage in dialogue and debate. This, however, must be strategically endorsed, and formal PAR processes put in place so that engagement in and learning through this community of practice informs how sustainability is interpreted within the emergent business curricula. In this way, curriculum renewal occurs at the nexus of teaching and research so that leading research enters curricula through this ongoing dialogue.

As a complex and contested body of knowledge (Reid and Petocz 2006), sustainability may not be unique. The PAR and the institutional enabling factors outlined in this paper could be useful for integrating other such complex and future-oriented concepts within curriculum. The boundary objects identified in this PAR may be found in other forms of curriculum development. Concepts such as sustainability can be continuously translated into malleable yet recognizable practical forms of knowing. These can then be applied or adapted in a diverse range of disciplines through ongoing debate and dialogue within the community of practice. Our study highlights the importance of considering how boundary objects are productive as they act as points of attraction for this specific form of curriculum development process, one that is built upon ongoing collegiate dialogue and PAR principles. Higher education institutions will then be capable of evolving the curricula developed through iterative PAR cycles, whereby academics are active constituents and disciplinary ways of knowing are continuously extended and renewed.

Boundary objects are not apolitical and can act to create, challenge or reinforce power structures (Oswick and Robertson 2009) which may or may not embody the ecological and social equity principles that underpin sustainability. When boundary objects are constructed and materialise within a community of practice and where there was a high degree of respect among the participants, participants tended to act with integrity and autonomy so as to deeply engage with the social and ecological discourses within their disciplines. That boundary objects can cause tensions that may block collaboration is also well known (Nicolini, Mengis, and Swan 2012; Oswick and Robertson 2009), and this occurred at many instances during the process when disciplinary based academics withdrew their support for the process. Yet this is the exact moment when the type of dialogic interaction around such tensions that characterizes boundary objects, is most useful (Star 2010). Such tensions can be likened to those identified by Turner et al. (2015) as being 'essential tensions', that typically pervade interdisciplinary interactions but can be productively managed through process-oriented and self-reflective practices. We suggest that purposefully engaging in a PAR process through a community of practice for curriculum development may be one way such tensions can be purposefully managed to be productive. The tensions should be revered, and the boundary objects themselves be introduced into curricula as contested. Not as resolved epistemic objects to be learnt but conveyed so they attract debate and dialogue.

Certainly in this study, academics used tensions arising between and within their disciplines to set a broader agenda to consider what 'ought to' be included to enable sustainability to be a founding rationale for business decision making. This occurred through a wide and deep consultation with academics across the faculty. As contestation and dialogue de-intensified, sustainability working party members moved closer to a common perspective of sustainability in business 
curricula, they were able to cooperate without consensus, to shift the dominant sustainability discourse away from an exclusively profit-orientated approach. Participatory inquiry and practice can generate such change (Kemmis and McTaggart 2005; Reason and Bradbury 2006). In this business school context, such change resulted in sustainability being prioritized as an area of research emphasis as well as curriculum development (Ralph and Stubbs 2014). Business schools can establish the conditions to enable academics to be active constituents of evolving curricula that prioritises complex social and ecological issues.

\section{Disclosure statement}

No potential conflict of interest was reported by the authors.

\section{Notes on contributors}

Dr Melissa Edwards is Director of Executive Programs and a Research Director at the Centre for Business and Social Innovation in the UTS Business School. She was a lead Cl on Australian Government Office of Learning and Teaching project to develop a Community of Practice to share excellence in Sustainability Education through an online platform (www.sustainability.edu.au) for which she was awarded a finalist in the Green Gown Awards for Excellence. She has led several cross- and trans-disciplinary teams to embed sustainability into business school curricula, including the development of a foundation undergraduate subject that challenges students to address 'wicked problems' and to design sustainable entrepreneurial solutions for which she received a University T\&L Citation. She currently chairs the UTS Business School cross-faculty Sustainability Working Party and is a member of the University Sustainability Research Committee. She co-chairs the Sustainability and Social Issues in Management stream at the Australian and New Zealand Academy of Management conference (2014-19) and has collaborated to develop a stream of research regarding Sustainability in Management Education (SiME) at the prestigious Academy of Management Conference. She has published on sustainability in business research in journals such as Organization and Environment and Business, Strategy and Environment.

Dr Paul Brown is a Senior Lecturer in Accounting in the UTS Business School and creative intelligence in the Faculty of Transdisciplinary Innovation. Paul specializes in production economics, innovative management practices and sustainability, and teaches management accounting, and creative intelligence and innovation. Paul has contributed to teaching and development teams for a range of courses which have been recognised as ground breaking, including the award-winning Bachelor of Creative Intelligence and Innovation. His teaching approach enables learning to iterate between divergent (creative) and convergent (analytical) modes, while being focussed on solving some of society's most challenging problems. He completed his PhD in 2009 and since his research revolves around the question of: How can organisational activity be structured and managed so as to be sustainable, within a sustainable global economy? Examples of two applied research projects are the Leadership \& Change for Energy Efficiency in Accounting \& Management, funded by the NSW Office of Environment \& Heritage; and, Accounting for value chain sustainability and competitive advantage, funded by the Australian Government Cotton Research and Development Corporation. Paul serves on the board of the Environmental Defenders Office NSW, which is an innovative community legal centre specializing in public interest environmental law.

Suzanne Benn is a Professor in the UTS Business School. She specialises in sustainability in the context of business, including in business education for sustainability. She has authored three books and more than 100 academic articles on associated topics.

Christopher Bajada is an Associate Professor of Economics at the UTS Business School, University of Technology Sydney. Chris has taught economics in a variety of undergraduate and postgraduate economics courses for which he was awarded the University of Technology Teaching Excellence Award and a National Teaching Award for Outstanding Contributions to Student Learning in Australian Higher Education. As Associate Dean (Teaching and Learning), Chris was instrumental in leading the change in the business school curriculum to incorporate sustainability across several undergraduate and postgraduate business courses. Chris has also worked on various projects in the area of sustainability including modelling the economic value of algae production and education focused research for the NSW Office of Environment and Heritage to develop strategies for improving energy efficient training for NSW organisations. Chris's research spans both micro and macroeconomics, with a special interest in the tax compliance. He has worked with the Australian Taxation Office as a member of the Cash Economy Task Force and his research has attracted national publicity. Chris has also published in the areas of curriculum design, circular economy, and management practices and their impact on productivity. 
Dr Robert Perey is a Research Associate with the Centre for Business and Social Innovation in the Management Discipline Group at the University of Technology Sydney, Australia. Previously, he was a Program Manager in the Australian Research Institute in Education for Sustainability at Macquarie University, Sydney. His work is transdisciplinary focusing on organisational and societal change. He has worked on projects ranging across biodiversity awareness in Culturally and Linguistically Diverse Communities (CALD); sustainability case study development for inclusion in MBA programs; investigating emerging business models, which promote circular flows of resources that now include waste as a valuable product; and designing and facilitating the series of degrowth professional development workshops at the Academy of Management conferences since 2011. His work is published in books and journal articles, and his research interests centre on ecological sustainability, complexity, social imaginaries, aesthetics, and the degrowth economy.

Dr Deborah Cotton is a Senior Lecturer in the Finance Discipline of the UTS Business School and teaches ethics and sustainability in finance and corporate finance. She has a PhD in Applied Finance for a thesis titled the Efficacy of Emissions Trading Schemes (2015). Her research interests include environmental, social and governance (ESG) issues in investment decisions. She was a lead investigator for the Social Impact Investment Market Study for the Department of Social Services in 2018. Within ESG her main interests include gender issues, human rights and climate change. She has worked with the Responsible Investment Association Australasia on an Investor Toolbox on Human Rights for practitioner use. She is a founding member of the Investing for Impact Initiative in the UTS Business School. She has recently published an ambiguity and risk and econometric analysis of Australian emissions markets and electricity prices in Energy Policy and the Journal of Finance and Risk Perspectives. Prior to this she published on carbon and energy prices in the Australasian Journal of Environmental Management, and on carbon trading in The Finsia Journal of Applied Finance. She has presented papers on climate change at conferences in Australia, China, Brazil, Greece and the United Kingdom.

Dr Walter Jarvis is the Director of the UTS Master of Management and a researcher and educator in leadership, corporate governance, and stewardship. His research investigates decision-making in business, foregrounding as a premise to management the moral-relational accountability of business leaders to regain public trust in enterprise management. In his research and teaching he draws on 20 plus years general management and consulting experience with local and international corporations, as well as formal qualifications in education and management learning. He coordinates and lectures subjects across management, leadership and stewardship. He has collaborated with Natalia for over 6 years on the development and design of a core post-graduate management subject (Managing, Leading and Stewardship) which has been recognized for its contribution to cultivating students' moral accountabilities by a UTS Learning \& Teaching citation. He has published on the cultivation of moral accountability in the Journal of Business Ethics Education (2016), on Threshold Concepts in the Business School Curriculum in Education and Training (2016), on The Impact of Corporate Governance on Compounding Inequality in Critical Perspectives on Accounting (2019) and has an article on Stewardship undergoing revision for the Academy of Management Learning and Education.

Gordon Menzies is an Associate Professor of Economics at UTS. He is a Commonwealth Scholar who read Economics at Oxford, and holds various awards related to his own postgraduate work, and his teaching and research at UTS. He introduced Environmental and Resource economics into the curriculum at UTS.

Dr lan McGregor is a Lecturer at UTS Business School. He has extensive experience in embedding sustainability in curriculum not only within UTS Business School but also within a Global Governance subject in the Global Studies degree for which he led the development. He has included environmental and social sustainability in both undergraduate and postgraduate strategy subjects and worked with colleagues in the UTS Business School to assist them in incorporating sustainability into the subjects that they were coordinating and/or teaching. His PhD thesis focused on the global politics of climate change and he was a Board Member of Climate Action Network Australia (CANA) for 5 years and continues to actively contribute to working groups within Climate Action Network (CAN) International. He has attended 7 UN Climate Summits, 5 as an Expert Advisor on the negotiations to one of the Least Developed Countries. In 2016, he was recognised with a "Green Hero" award by UTS for his work on Climate Change both at UTS and beyond. Climate change issues feature strongly in his teaching and ongoing research and he was co-author of a book chapter published on Climate Change Impacts on Small Island Developing States in a Cambridge University Press book on Climate Change and Ocean Governance.

Katrina Waite Katrina is a lecturer and academic developer in the university's central teaching and learning unit. She works with academics and professionals in the development of curriculum. She also supports academics in developing teaching and learning approaches which foster interaction, with a focus on approaches which work well in culturally diverse classes, and which minimise subtle gender discrimination. Current research interests include the practice of curriculum change within higher education, and in particular, business and management education. She has undertaken research on the inclusion of ethics into business curriculum, and has 
worked on the development of interdisciplinary business subjects. She is also a member of the project team for the national Office for Learning and Teaching Project 'Student Engagement in university decision-making and governance - towards a more systemically inclusive student voice'.

\section{ORCID}

Melissa Edwards (iD http://orcid.org/0000-0002-3627-7314

Christopher Bajada iD http://orcid.org/0000-0003-0590-1492

Robert Perey (iD http://orcid.org/0000-0002-1954-7781

Deborah Cotton (iD http://orcid.org/0000-0003-1605-6749

Gordon Menzies (iD http://orcid.org/0000-0003-4133-2282

Katrina Waite (iD http://orcid.org/0000-0001-8851-7423

\section{References}

AACSB. 2013. "Eligibility Procedures and Accreditation Standards for Business Accreditation. Accessed March 2019. https://www.aacsb.edu/-/media/aacsb/docs/accreditation/business/standards-and-tables/2018-business-standards. ashx?la=en\&hash=B9AF18F3FA0DF19B352B605CBCE17959E32445D9.

Akrivou, Kleio, and Hilary Bradbury-Huang. 2015. “Educating Integrated Catalysts: Transforming Business Schools toward Ethics and Sustainability." Academy of Management Learning \& Education 14 (2): 222-240. doi:10.5465/ amle.2012.0343.

Andersson, Pernilla, and Johan Öhman. 2016. "Logics of Business Education for Sustainability." Environmental Education Research 22 (4): 463-479. doi:10.1080/13504622.2015.1015493.

Bechky, Beth. A. 2003. "Sharing meaning across occupational communities: The transformation of understanding on a production floor." Organization Science 14 (3): 312-330. doi:10.1287/orsc.14.3.312.15162

Benn, Suzanne, and Andrew Martin. 2010. "Learning and Change for Sustainability Reconsidered: A Role for Boundary Objects." Academy of Management Learning \& Education 9 (3): 397-412. doi:10.5465/amle.9.3.zqr397.

Benn, Suzanne, Melissa Edwards, and Tamsin Angus-Leppan. 2013. "Organizational Learning and the Sustainability Community of Practice: The Role of Boundary Objects." Organization \& Environment 26 (2): 184-202. doi:10.1177/ 1086026613489559.

Birdsall, Sally. 2015. "Analysing Teachers' Translation of Sustainability Using a PCK Framework." Environmental Education Research 21 (5): 753-776. doi:10.1080/13504622.2014.933776.

Buckler, Carolee, and Heather Creech. 2014. "Shaping the Future we Want: UN Decade of Education for Sustainable Development (2005-2014) Final Report." United Nations Educational, Scientific and Cultural Organization, Luxembourg. ISBN 978-92-3-100053-9

Bursztyn, Marcel, and José Drummond. 2014. "Sustainability Science and the University: Pitfalls and Bridges to Interdisciplinarity." Environmental Education Research 20 (3): 313-332. doi:10.1080/13504622.2013.780587.

Clark, Barbara, and Charles Button. 2011. "Sustainability Transdisciplinary Education Model: Interface of Arts, Science, and Community (STEM)." International Journal of Sustainability in Higher Education 12 (1): 41-54. doi:10. $1108 / 14676371111098294$.

Dieleman, Hans, and Don Huisingh. 2006. "Games by Which to Learn and Teach about Sustainable Development: Exploring the Relevance of Games and Experiential Learning for Sustainability." Journal of Cleaner Production 14 (9-11): 837-847. doi:10.1016/j.jclepro.2005.11.031.

Doh, Jonathan P, and Peter Tashman. 2014. "Half a World Away: The Integration and Assimilation of Corporate Social Responsibility, Sustainability, and Sustainable Development in Business School Curricula." Corporate Social Responsibility and Environmental Management 21 (3): 131-142. doi:10.1002/csr.1315.

Gal, Uri, Kalle Lyytinen, and Youngjin Yoo. 2008. "The Dynamics of IT Boundary Objects, Information Infrastructures, and Organisational Identities: The Introduction of 3D Modelling Technologies into the Architecture, Engineering, and Construction Industry." European Journal of Information Systems 17 (3): 290-304. doi:10.1057/ejis.2008.13.

Dean, B. A., B. Gibbons, and S. Perkiss. 2019. "An Experiential Learning Activity for Integrating the United Nations Sustainable Development Goals into Business Education." Social Business 8 (4): 387-409. doi:10.1362/ $204440818 \times 15445231830058$.

Hansmann, Ralf. 2010. "Sustainability Learning": An Introduction to the Concept and Its Motivational Aspects." Sustainability 2 (9): 2873-2897. doi:10.3390/su2092873.

Hawkins, Beverley, Annie Pye, and Fernando Correia. 2017. "Boundary Objects, Power, and Learning: The Matter of Developing Sustainable Practice in Organizations." Management Learning 48 (3): 292-310. doi:10.1177/ 1350507616677199.

Heron, John, and Peter Reason. 1997. "A Participatory Inquiry Paradigm." Qualitative Inquiry 3 (3): 274- 294. doi:10. $1177 / 107780049700300302$. 
Heron, John, and Peter Reason. 2006. "The Practice of Cooperative Inquiry." In Handbook of Action Research: The Concise Paperback Edition, edited by Peter Reason, P. \& Hilary Bradbury, 144-154. London, Thousand Oaks, New Delhi: Sage.

Kemmis, Stephen, and Robin McTaggart. 2005. "Communicative Action and the Public Sphere." In The Sage Handbook of Qualitative Research, edited by Norman K. Denzin and Yvonne S. Lincoln, 559-603. USA: Sage Publications.

Louw, Jonathan. 2015. "Paradigm Change" or No Real Change at All? A Critical Reading of the UN Principles for Responsible Management Education." Journal of Management Education 39 (2): 184-208. doi:10.1177/ 1052562914547965.

Macpherson, Allan, and Oswald Jones. 2008. "Object-Mediated Learning and Strategic Renewal in a Mature Organization." Management Learning 39 (2): 177-201. doi:10.1177/1350507607087580.

Max-Neef, Manfred A. 2005. "Foundations of Transdisciplinarity." Ecological Economics 53 (1): 5-16. doi:10.1016/j.ecolecon.2005.01.014.

Muff, Katrin, Agnieszka Kapalka, and Thomas Dyllick. 2017. "The Gap Frame-Translating the SDGs into Relevant National Grand Challenges for Strategic Business Opportunities." The International Journal of Management Education 15 (2): 363-383. doi:10.1016/j.ijme.2017.03.004.

Nicolini, Davide, Jeanne Mengis, and Jacky Swan. 2012. "Understanding the Role of Objects in Cross-Disciplinary Collaboration." Organization Science 23 (3): 612-629. doi:10.1287/orsc.1110.0664.

Onuki, Motoharu, and Takashi Mino. 2009. "Sustainability Education and a New Master's Degree, the Master of Sustainability Science: The Graduate Program in Sustainability Science (GPSS) at the University of Tokyo." Sustainability Science 4 (1): 55. doi:10.1007/s11625-009-0073-5.

Oswick, Cliff, and Maxine Robertson. 2009. "Boundary Objects Reconsidered: From Bridges and Anchors to Barricades and Mazes." Journal of Change Management 9 (2): 179-193. doi:10.1080/14697010902879137.

Page, Robert A, and Kirsten A. Collins. 2010. "The Green MBA: A Competing Values Matrix." Competitiveness Review 20 (1): 62-71. doi:10.1108/10595421011019984.

Painter-Morland, M., E. Sabet, P. Molthan-Hill, H. Goworek, and S. de Leeuw. 2016. "Beyond the Curriculum: Integrating Sustainability into Business Schools." Journal of Business Ethics 139 (4): 737-754. doi:10.1007/s10551015-2896-6.

Porter, Terry, and José Córdoba. 2009. "Three Views of Systems Theories and Their Implications for Sustainability Education." Journal of Management Education 33 (3): 323-347. doi:10.1177/1052562908323192.

Ralph, Meredith, and Wendy Stubbs. 2014. "Integrating Environmental Sustainability into Universities." Higher Education 67 (1): 71-90. doi:10.1007/s10734-013-9641-9.

Rasche, Andreas, and Manuel Escudero. 2010. "Leading Change - the Role of the Principles of Responsible Management Education." Journal of Business and Economic Ethics 10 (2): 244- 250. doi:10.5771/1439-880X-2009-2-244.

Reason, Peter, and Hilary Bradbury. 2006. "Introduction: Inquiry and Participation in Search of a World Worthy of Human Aspiration." In Handbook of Action Research: The Concise Paperback Edition, edited by Peter Reason and Hilary Bradbury, 1-14. London, Thousand Oaks: Sage.

Reid, Alan. 2019. "Blank, Blind, Bald and Bright Spots in Environmental Education Research." Environmental Education Research 25 (2): 157-171. doi:10.1080/13504622.2019.1615735.

Reid, Anna, and Peter Petocz. 2006. "University Lecturers' Understanding of Sustainability." Higher Education 51 (1): 105-123. doi:10.1007/s10734-004-6379-4.

Rusinko, Cathy A. 2010. "Integrating Sustainability in Management and Business Education: A Matrix Approach." Academy of Management Learning \& Education 9 (3): 507-519. doi:10.5465/amle.9.3.zqr507.

Sachs, Jeffrey D. 2012. "From Millennium Development Goals to Sustainable Development Goals." The Lancet 379 (9832): 2206-2211. doi:10.1016/S0140-6736(12)60685-0.

Shrivastava, Paul. 2010. "Pedagogy of Passion for Sustainability." Academy of Management Learning \& Education 9 (3): 443-455. doi:10.5465/amle.9.3.zqr443.

Star, Susan Leigh. 2010. "This is Not a Boundary Object: Reflections on the Origin of." a Concept." Science, Technology, \& Human Values 35 (5): 601-617. doi:10.1177/0162243910377624.

Star, Susan Leigh, and James R. Griesemer. 1989. "Institutional Ecology, Translations' and Boundary Objects: Amateurs and Professionals in Berkeley's Museum of Vertebrate Zoology, 1907-39." Social Studies of Science 19 (3): 387-420. doi:10.1177/030631289019003001.

Starik, Mark, Gordon Rands, Alfred A. Marcus, and Timothy S. Clark. 2010. "From the Guest Editors: In Search of Sustainability in Management Education." Academy of Management Learning \& Education 9 (3): 377-383. doi:10. 5465/amle.9.3.zqr377.

Tress, Bärbel, Gunther Tress, and Gary Fry. 2005. "Integrative Studies on Rural Landscapes: Policy Expectations and Research Practice." Landscape and Urban Planning 70 (1-2): 177-191. doi:10.1016/j.landurbplan.2003.10.013.

Turner, V. Kelly, Karina Benessaiah, Scott Warren, and David Iwaniec. 2015. "Essential Tensions in Interdisciplinary Scholarship: Navigating Challenges in Affect, Epistemologies, and Structure in Environment-Society Research Centers." Higher Education 70 (4): 649-665. doi:10.1007/s10734-015-9859-9. 
Waddock, Sandra, and Josep M. Lozano. 2013. "Developing More Holistic Management Education: Lessons Learned from Two Programs." Academy of Management Learning \& Education 12 (2): 265-284. doi:10.5465/amle.2012. 0002.

Waddock, Sandra, Andreas Rasche, Patricia H. Werhane, and Gregory Unruh. 2010. "The Principles for Responsible Management Education." In Towards Assessing Business Ethics Education, edited by Diane L. Swanson and Dann G. Fisher, 13-28. USA: Information Age Publishing.

Warburton, Kevin. 2003. "Deep Learning and Education for Sustainability." International Journal of Sustainability in Higher Education 4 (1): 44-56. doi:10.1108/14676370310455332.

Wenger, E. 1998. Communities of Practice: Learning, Meaning and Identity. Cambridge: Cambridge University Press. Zaman, Gheorghe, and Zizi Goschin. 2010. "Multidisciplinarity, Interdisciplinarity and Transdisciplinarity: Theoretical Approaches and Implications for the Strategy of Post-Crisis Sustainable Development." Theoretical \& Applied Economics 17 (12): 5-20.

\section{Appendix A: Reflections of the evolution of sustainability in the undergraduate curriculum}

\section{A.1: $\quad$ From the perspective of a management academic}

As an advocate for sustainability in business curricula, I was pleased to see this included in a PLO following the Bachelor of Business review in 2010. Due to my close involvement in climate change and sustainability research, this seemed to me totally uncontroversial and I expected that it would be endorsed by my colleagues across the Business School. Most of my colleagues in the Management Discipline Group endorsed that sustainability should be part of the business curriculum. I was therefore a bit surprised about the resistance we encountered in some of the other Discipline Groups in gaining cooperation to embedding sustainability in the curriculum.

As a founding member of the Sustainability Working Party, I was one of the early proponents of the Nested System Model of Environmentally Sustainable Development (see Figure 3) which became a boundary object. My view was and still is that society had to constrain the economy and business so that it remained within ecological limits as represented by the nested system model. This was reflected in the part of the definition of Sustainability included in the PLOv1:- "A fully sustainable business operates to maintain and restore stocks of natural resources and to improve human and societal wellbeing".

In reflection, the evolution of the PLO which agreed a more comprehensive and relevant definition of sustainability, and the different levels of learning in relation to it, was a major factor in embedding sustainability in the curriculum. After much deliberation, the sustainability definition was formally endorsed by the Business School and the PLOv2 acted as a boundary object as we had ongoing discussions with Heads of Discipline Groups and academics teaching in the various disciplinary subjects about how sustainability could be embedded in the curriculum. This was largely achieved, as the PLOv2 is assured across all programs, however, the level of sustainability learning still varies across the different disciplines.

It also helped greatly if an academic from each discipline was an active and supportive participant in the Sustainability Working Party, as that meant he or she knew who in that discipline was likely to be supportive and where the resistance was likely to be met. Ideally, he or she sought the Head of Discipline's endorsement for the inclusion of sustainability in the curriculum. This approach varied depending on how well disposed the Head of Discipline was to sustainability learning, and even when endorsed, other Academics could be quite resistant. In the initial phase, we had problems getting sustainability embedded in the Finance and Marketing majors. This changed in Finance when we got a supportive senior staff member on the Sustainability Working Party. Appendix A.2 documents that colleague's experience and challenges in getting inclusion of sustainability in the Finance curricula.

\section{A.2: $\quad$ From the perspective of a finance academic}

The discussion on sustainability within the Finance group had extremely mixed reactions, ranging from 'what has this to do with finance?' through to 'we do this in finance anyway - our goal of increasing shareholder wealth is prefaced upon the assumption that our business will be sustainable i.e.not about to go into liquidation for any reason'. So refining the definition of sustainability for finance was a key to moving forward. I took a role to open up discussion about what do we mean by sustainability and what sort of sustainability issues can send a company into liquidation? One member of the group came up with the issues of non-renewable resources and the impacts of climate change having profound impacts on the firm's cash flows and the risk of these cash flows. Introductory finance and many of the following subjects in any business degree are based on gaining an understanding of the risks a firm faces and how to value/quantify them. So while not suggesting to the group that sustainability needs to be exclusively about environmental issues per se, these issues come up as real factors in risk management of the firm. This type of discussion is interesting for most finance academics. From both a qualitative and quantitative 
angle, and we have a very strong quantitative emphasis in our discipline group, this is a very interesting problem. How do we quantify the risks? In terms of probabilities of occurrence? Are they cumulative? What are the effects of these occurrences etc.? Finite resources affect nearly every industry imaginable and without much expenditure to date on any alternatives to coal and gas in Australia the cost increases and required changes to how a firm operates as a consequence provide a vast number of areas of interest to quantitative and more qualitative finance academics/researchers. Having come to a clearer understanding the general business school sustainability definition was refined: 'Sustainable finance is the practice of enhancing long term economic and social value through financial models and systems, including markets, institutions and instruments.' We were then able to come up with a consensus on what could be included in our very overcrowded curriculum and in what subjects it is most suitable for the purposes of developing and assuring the PLOv2. Isolating the assessment for sustainability was more problematic and will most likely be a work in progress as the subject coordinators come to terms with how best to do this. Recently a subject on Ethics and Sustainability in Finance was added to our Masters in Finance degree. It would be wrong to assume the practical nature of finance academics does not lend itself easily to the practical nature of ensuring sustainability from all perspectives. 